\title{
Extrusion Cooking using Fruits Peels, Whole Cereals and Grains
}

\author{
Jose Luis Ramirez Ascheri ${ }^{*}$, Ronel Joel Bazan Colque ${ }^{2}$, Luana Manfioletti Borsoi ${ }^{3}$, Diego Palmiro Ramirez \\ Ascheri ${ }^{4}$, Arturo Melendez Arevalo ${ }^{2}$ and Erika Madeira Moreira Da Silva ${ }^{3}$
}

${ }^{1}$ Food Extrusion and Physical Properties Lab, Brazil

${ }^{2}$ Federal Rural University of Rio de Janeiro (PPGCTA-UFRRJ), Brazil

${ }^{3}$ Federal University of Espirito Santo-(PPGNS-UFES), Brazil

${ }^{4}$ Campus of Exact and Technological Sciences, Brazil

*Corresponding author: Jose Luis Ramirez Ascheri, Researcher at Embrapa Food Technology, Food Extrusion and Physical Properties Lab, Brazil.

Received Date: May 23, 2019

Published Date: May 28, 2019

\begin{abstract}
New equipment, new accessories, better processing techniques in the area of food extrusion, coupled with the possibility of exploring much more raw materials available. In this way, processing whole grains, using agro-industry by-products, is becoming more and more feasible, with beneficial results of value added. As a result, products of better quality from a nutritional point of view, with sensory quality and lower cost possibilities, as well as serving groups that need gluten-free food.
\end{abstract}

Keywords: Extrusion cooking; Products development; Parameters processing; Quality criteria; Foods; Nutrition values

\section{Introduction}

Several treatises describe thermoplastic extrusion as an important technology in food product development. Mainly for the possibility of using several ingredients, either alone or in formulations. Recently we have gained high market values products with greater health. In this context, the use of grains and whole grains is an important market in the preparation of breakfast foods, or special foods for children or the elderly, which contain significant nutritional values: antioxidants, fibers, vitamins and, possibly, better protein and free gluten [1].

\section{Production Alternatives}

Through the extrusion, it is possible to obtain products of better nutritional quality. Thus, we can mention sorghum, if we consider, the different existing varieties [2], there are those that have high antioxidants levels, these, in turn, can be prepared and used in the elaboration of foods such as morning cereals, porridge, pregelatinized flours for use as an input in other food preparations, among other alternatives. On the other hand, in order to provide a product to improve fiber intake, day-to-day, extrusion tests were performed using mixtures of passion fruit peel flour to rice flour [3] in order to obtain a pre-cooked flour, easy to prepare, in the form of a porridge or be ingested with milk or juices. In this way, to take advantage of this natural resource and that can be used to improve the digestive system, which also suggests possibilities of use in people with diabetes or mainly pre-diabetics $[4,5]$.

An interesting industrial coproduct, in the manufacture of analogs of jabuticaba wine (Plinia cauliflora), corresponds to peel. This material, already analyzed by several researchers, rich in antioxidants that after dehydration, in the form of flour, could be used, in mixtures with cereals, like rice, in the preparation of precooked mixed flour of fast preparation. Although the heat treatment during food extrusion can generate some loss of the natural antioxidants, there is always a surplus that can be harnessed $[6,7]$.

To attend populations of extreme food need, as in nutritional campaigns in countries with populations of extreme poverty, a mixed flour, of low cost, was elaborated using corn grits and whole 
soybean meal flour in various proportions (soybean/maize: 40/60, $50 / 50,60 / 40$ ). These flours have nutritional properties ranging from $25-30 \%$ protein, good biological value, and caloric, lipid content compatible with the needs for these groups. The flour result has a good degree of solubility when required in the use of a preparation of beverages, or porridges, soups, etc. All this with ease preparation, only adding water is cold or hot according to the required objective $[8,9]$.

Although the production of the Andean pseudocereals (Chenopodium quinoa willd, Amaranthus spp) is limited by their small production area in the Andes of Peru and Bolivia, they have very high nutrient values. In this sense, breakfast cereals are already available using these grains. The advantage, in this case, is that these grains can be processed in their integral form. Only depending on its quality, the proper handling of the extrusion parameters [10], to guarantee the least possible loss of its essential amino acids.

On the other hand, the use of green fruits, as in the case of certain varieties of banana, can be used as functional ingredients. Thus [11] prepare banana flakes with and without peel and processed by extrusion to study their characteristics: gelatinization, resistant starch, dietary fiber, and functional properties, such as pasting properties, concluded that the product has a high content of nondigestible carbohydrates, which indicates its potential in diabetic patients or in need of a diet to reduce body weight.

It is important to emphasize that, due to this technology, food thermoplastic extrusion allows the elaboration of several convenience products, and it offers finished products for immediate use, in which they can be mixed with a variety of ingredients, including enrichment with sources of minerals, amino acids, bioactive, provided that the appropriate tools are used during the elaboration so as not to diminish their bioavailability.

\section{Conclusion}

With the possibility of having different forms of control in the extrusion system, new accessories, excellent pre-conditioners, different shapes and configurations of the extrusion system, handling of raw materials, proper grinding, makes possible better conditions for use of raw materials, or with high fiber content. This will be the reason to make available to the consumer market better products in both sensory and nutritional quality. Still with the possibilities of a better price and for those in need of products high in fiber and gluten-free.

\section{Acknowledgement}

The authors would like to thank them for research stimulation grant to FAPERJ, FAPES, FAPEG, CAPES and CNPq for their financial support.

\section{Conflict of Interest}

No Conflict of Interest.

\section{References}

1. Patricia Morales, Laura Cebadera Miranda, Rosa M Cámara, Filipa S Reis, Lillian Barros, et al. (2015) Lentil flour formulations to develop new snack-type products by extrusion processing: Phytochemicals and antioxidant capacity. Journal of Functional Foods 19: 537-544.

2. Davy Chávez, José Ascheri, Amanda Martins, Carlos Carvalho, Cristiany Bernardo, et al. (2018) Sorghum, an alternative cereal for gluten-free product. Rev Chil Nutr 45(2): 169-177.

3. Priscila Leal da Silva Alves, Jose D J Berrios, James Pan, José Luis Ramirez Ascheri (2018) Passion fruit shell flour and rice blends processed into fiber-rich expanded extrudates, CyTA. Journal of Food 16(1): 901-908.

4. Anisha Chandalia, Abhimanyu Garg, Dieter Lutjohann, Klaus Von Bergmann, Scott M Grundy, et al. (2000) Beneficial effects of high dietary fiber intake in patients with type 2 diabetes mellitus. $\mathrm{N}$ Engl J Med 342(19): 1392-1398.

5. Huma Bader Ul Ain, Farhan Saeed, Aftab Ahmed, Muhammad Asif Khan, Bushra Niaz, et al. (2019) Improving the physicochemical properties of partially enhanced soluble dietary fiber through innovative techniques: A coherent review. J Food Process Preserv 43(4): e13917.

6. Ascheri Diego Palmiro Ramirez, Ascheri JLR, Carvalho CWP, Devilla AI (2007) Propriedades Termodinâmicas De Adsorção De Água De Farinhas Mistas Pré-gelatinizadas de bagaço de jabuticaba e arroz: Efeito dos parâmetros de extrusão. Brazilian Journal of Food Technology (ITAL) 10: 183-193.

7. Letícia Mazzarino, Heloísa da Silva Pitz, Ana Paula Lorenzen Voytena, Adriana Carla Dias Trevisan, Rosa Maria Ribeiro-Do-Valle, et al. (2018) Jaboticaba (Plinia peruviana) extract nanoemulsions: development, stability, and in vitro antioxidant activity. Drug Dev Ind Pharm 44(4): 643-651.

8. Ascheri Diego Palmiro Ramirez, Silva PHXF, Ascheri JLR, Carvalho CWP (2009) Comportamento reológico de farinha mista extrusada de bagaço de jabuticaba e arroz. Revista Processos Químicos 2: 68-73.

9. Nascimento KO, Wang Sin Huei, Nascimento Talita P, Batista GS, Ascheri JLR (2007) Farinhas de trigo e soja (80:20) pré-cozidas por extrusão para sopas cremosas semi-prontas. Alimentos e Nutrição (UNESP) 18: 61-68.

10. Fernandes SM, Wang SH, Ascheri JLR, Oliveira M, Cosra SAJ (2003) Harina de grits de maíz-soya (70:30) precocida por extrusión para uso como sopa cremosa semi instantanea. Alimentaria (Madrid) 40: 89-96.

11. Garcia Valle DE, Bello Perez LA, Flores Silva PC, Agama Acevedo Eand Tovar J (2019) Extruded Unripe Plantain Flour as an Indigestible Carbohydrate-Rich Ingredient. Front Nutr 6: 2. 